Article

\title{
Conversion of Carbon Monoxide into Methanol on Alumina-Supported Cobalt Catalyst: Role of the Support and Reaction Mechanism-A Theoretical Study
}

\author{
Nguyen Ngoc Ha, Nguyen Thi Thu Ha, Nguyen Binh Long and Le Minh Cam* \\ Faculty of Chemistry, Hanoi National University of Education, Ha Noi 100000, Vietnam; \\ hann@hnue.edu.vn (N.N.H.); ntt.ha@hnue.edu.vn (N.T.T.H.); binhlongsonla@gmail.com (N.B.L.) \\ * Correspondence: camlm@hnue.edu.vn; Tel.: +84-989-886-242
}

Received: 12 November 2018; Accepted: 19 December 2018; Published: 23 December 2018

\begin{abstract}
Density functional theory (DFT) was used to calculate the step-by-step hydrogenation of carbon monoxide (CO) to form methanol over a $\mathrm{Co}_{4}$ cluster $/ \mathrm{Al}_{2} \mathrm{O}_{3}$ surface. A three-dimensional $\mathrm{Co}_{4}$ tetrahedral structure was selected to explore its interaction with the supporting $\mathrm{Al}_{2} \mathrm{O}_{3}$ (104) surface. $\mathrm{Co}_{4}$ chemically reacted with $\mathrm{Al}_{2} \mathrm{O}_{3}$ to form a new chemical system. The calculated results show that $\mathrm{Al}_{2} \mathrm{O}_{3}$ support has strengthened the $\mathrm{Co}_{4}$ catalyst during the reaction since the formation of the $\mathrm{Co}-\mathrm{O}$ bond. Loading $\mathrm{Co}_{4}$ on the $\mathrm{Al}_{2} \mathrm{O}_{3}$ surface increases $\mathrm{CO}$ adsorption ability but decreases the dissociation ability of $\mathrm{C}-\mathrm{O}$ to produce hydrocarbons. As such, $\mathrm{CH}_{3} \mathrm{OH}$ formation becomes more favorable both kinetically and thermodynamically on $\mathrm{Co}_{4} / \mathrm{Al}_{2} \mathrm{O}_{3}$. In $\mathrm{CO}$ hydrogenation, methanol was synthesized through a $\mathrm{CO}$ reaction with hydrogen via either an Eley-Rideal or Langmuir-Hinshelwood pathway to form the intermediates $\mathrm{C}^{*}-\mathrm{O}-\mathrm{H}, \mathrm{H}-\mathrm{C}^{*}-\mathrm{OH}, \mathrm{H}_{2}-\mathrm{C}^{*}-\mathrm{OH}$, and finally the hydrogenation of $\mathrm{H}_{2}-\mathrm{C}^{*}-\mathrm{OH}$ to methanol with both hydrogenation steps forming $\mathrm{C}^{*}-\mathrm{OH}$ and final product as rate-limiting. These results showed that the interaction between $\mathrm{Co}, \mathrm{Al}_{2} \mathrm{O}_{3}$ and $\mathrm{H}_{2}$ pressure can change the pathway of $\mathrm{CO}$ hydrogenation on $\mathrm{Co} / \mathrm{Al}_{2} \mathrm{O}_{3}$ and it may, therefore, influence distribution of the final products.
\end{abstract}

Keywords: density functional theory; $\mathrm{Co}_{4}$ cluster; $\mathrm{Al}_{2} \mathrm{O}_{3}$; support; adsorption; mechanism; methanol

\section{Introduction}

Methanol synthesis by carbon monoxide $(\mathrm{CO})$ and carbon dioxide $\left(\mathrm{CO}_{2}\right)$ hydrogenation has been widely studied both experimentally and theoretically [1-6] because methanol is an important raw material of crucial importance in the chemical and energy industries.

In recent years oxide-supported metal catalysts have been extensively studied for $\mathrm{CO}$ hydrogenation to methanol such as modified catalysts of the Fischer-Tropsch process or Cu-based catalysts [7-12], Mo-based catalysts [13-16], and cobalt nanoparticles [17-20]. However, the methanol selectivity and catalytic stability remain rather poor. Thus, the development of a good catalyst with high selectivity and stability is required. In order to improve the methanol yield, many efforts have been made to understand the reaction mechanism and to suggest different reaction pathways to gain methanol via hydrogenation of $\mathrm{CO}$ and $\mathrm{CO}_{2}$.

Many studies have been devoted to the reaction mechanism over catalysts, controversies still remain. In the work done by $\mathrm{Li}$ et al. [21] a reaction mechanism on the transition metal (Fe, Co or $\mathrm{Ni}$ ) promoted $\mathrm{MoS}_{2}$ - based catalyst was proposed. Different reaction pathways on different catalytic phases $\left(\mathrm{MS}_{\mathrm{x}}\right.$ and $\mathrm{M}-\mathrm{KMoS}$ ) were suggested. On the $\mathrm{MS}_{\mathrm{x}}$ phase, $\mathrm{CO}$ dissociates and is subsequently hydrogenated into $\mathrm{CH}_{\mathrm{x}}$ and methane while on the mixed M-KMoS phase non-dissociative adsorbed 
CO inserts into a metal-methyl carbon bond producing an oxygenate precursor, which upon further hydrogenation or dehydration forms mixed $\mathrm{C}^{2+}$ oxygenates and hydrocarbons.

CO hydrogenation on these two $\mathrm{MoS}_{2}$ (10-10) surfaces was also investigated by Shi et al. [22] using density functional theory (DFT) calculations. Their results show that the route for the CO hydrogenation is the following:

$$
\begin{gathered}
\mathrm{CO}+\mathrm{H} \rightarrow \mathrm{HCO} \\
\mathrm{HCO}+\mathrm{H} \rightarrow \mathrm{H}_{2} \mathrm{CO} \\
\mathrm{H}_{2} \mathrm{CO}+\mathrm{H} \rightarrow \mathrm{H}_{2} \mathrm{COH} \\
\mathrm{H}_{2} \mathrm{COH} \rightarrow \mathrm{OH}+\mathrm{CH}_{2} \\
\mathrm{CH}_{2}+\mathrm{H} \rightarrow \mathrm{CH}_{3} \\
\mathrm{CH}_{3}+\mathrm{H} \rightarrow \mathrm{CH}_{4}
\end{gathered}
$$

Studt et al. [11] proposed that the hydrogenation of $\mathrm{CO}$ occurs at the carbon end of adsorbed $\mathrm{CO}$. Firstly, $\mathrm{HCO}$ is formed following by $\mathrm{H}_{2} \mathrm{CO}$ and finally to $\mathrm{H}_{3} \mathrm{CO}$. The last step in the reaction cascade to yield methanol is the hydrogenation of methoxy. Meanwhile, the hydrogenation of the oxygen end generating $\mathrm{COH}, \mathrm{HCOH}$ and $\mathrm{H}_{2} \mathrm{COH}$ intermediates possessed much higher barriers and all intermediates have higher energy than their carbon hydrogenated counterparts

Besides controversy about the mechanism, there is also no general agreement in the nature of the active site(s) and the effect of oxide support. It has been well established that due to the strong metal-support interactions a support can remarkable affect the active metal dispersion, reducibility, which then have an important influence on the catalytic activity [23]. Ramírez et al. [23] who studied the behavior of cobalt-based catalysts supported on several metal oxides in the $\mathrm{CO}_{2}$ methanation reaction at atmospheric pressure and low temperatures $\left(200-300{ }^{\circ} \mathrm{C}\right)$ found that apart from the Co particle size and oxidation state of active species, the catalytic activity and selectivity can also be affected by the nature of the support. Zuo et al. [24] suggested while hydrogenation of CO over metallic $\mathrm{Cu}$ does not generate methanol, the methanol can be synthesized from $\mathrm{CO}$ hydrogenation over $\mathrm{Cu} / \mathrm{ZnO}$ due to a strong synergetic interaction between metallic $\mathrm{Cu}$ and the oxide support $\mathrm{ZnO}$. In the work done by Lee et al. [25] the effect of the support and the interaction of $\mathrm{Cu}$ species with different supports were studied. The authors indicated that over zinc supported catalysts a higher conversion $(70 \%)$ and selectivity towards higher alcohols $(70 \%)$ were obtained. However, Medford et al. [26] indicated that the reaction was inhibited by the presence of very low $\mathrm{CO}_{2}$ concentration.

$\gamma-\mathrm{Al}_{2} \mathrm{O}_{3}$ is the most common inorganic oxide which is used as a support since its excellent thermal stability, fine particle size, high surface area and wide range of chemical, physical, and catalytic properties. In the work of Prasad et al. [27], iron-based catalysts dispersed on different supports have been extensively investigated. Among studied supports, the performance of $\gamma-\mathrm{Al}_{2} \mathrm{O}_{3}$ is best, followed by silicas and titanias. The good performance of may be attributed to the strong metal-support interaction, which results in well dispersed catalyst and hinders catalyst sintering. Reuel et al. [28] studied $10 \mathrm{wt}$ \% Co catalysts supported on $\mathrm{MgO}$, carbon, $\mathrm{SiO}_{2}$ and $\mathrm{Al}_{2} \mathrm{O}_{3}$. They found that the specific activity in the hydrogenation of carbon monoxide depends on the nature of the support in the following order: $\mathrm{MgO}<$ carbon $<\mathrm{SiO}_{2}<\mathrm{Al}_{2} \mathrm{O}_{3}$.

Theoretically, the mechanism and reaction pathways of $\mathrm{CO}$ hydrogenation are also extensively studied. Recently, theory has been recognized as an important tool in the design and optimization of catalysts for many applications $[29,30]$. Among theoretical methods used to study the electronic configurations and properties of many-body systems, in particular catalytic reactions, DFT is known as a versatile and effective method. The fundamental aspect of the DFT method is that the characteristics of many-electron systems can be using the electron density which depends only on the three Cartesian variables. Using the DFT approach, computational accuracy can be significantly increased without the additional increase in the computational costs. Due to its advances, DFT can simulate catalytic 
process at surfaces with the detail and accuracy required for calculated results to compare with experiments [31]. This understanding allows theoretical optimization for better catalysts.

Using periodic DFT calculations Andersen et al. [15] investigated the influence of K-doping on $\mathrm{MoS}_{2}$ activity in the $\mathrm{CO}$ hydrogenation. They found that doping $\mathrm{K}$ created $\mathrm{K}-\mathrm{O}$ and $\mathrm{K}-\mathrm{C}$ bonding on the $\mathrm{MoS}_{2}$ surface and hence enhanced the CO adsorption. The DFT calculations show that K-doping promotes the formation of mixed higher $\mathrm{C}_{2+}$ oxygenates. Reimers et al. [30] studied theoretically the catalytic activities of $\mathrm{Zn}, \mathrm{Ce}$ and $\mathrm{Ga}$ oxides in the consecutive hydrogenation reactions of the $\mathrm{CO}$ molecule. Their calculated results indicated that the methanol formation proceeds via formyl (HCO), followed by the formation of formaldehyde $\left(\mathrm{H}_{2} \mathrm{CO}\right)$, then methoxy $\left(\mathrm{H}_{3} \mathrm{CO}\right)$ and, finally, methanol.

In the study of Studt et al. [11] DFT results revealed that over $\mathrm{Cu}(211)$ the $\mathrm{CO}$ hydrogenation occurs at the carbon end of adsorbed $\mathrm{CO}$ and the formation of methanol is processed through $\mathrm{HCO}$, $\mathrm{H}_{2} \mathrm{CO}, \mathrm{H}_{3} \mathrm{CO}$ intermediates. In contrast, hydrogenation at the oxygen end will process via $\mathrm{COH}$, $\mathrm{HCOH}$ and $\mathrm{H}_{2} \mathrm{COH}$ intermediates with much higher barriers.

A DFT study has been conducted by Dou et al. [32] to study the effect of $\mathrm{ZrO}_{2}$ support on the catalytic behavior of $\operatorname{In}_{2} \mathrm{O}_{3}$ in the methanol synthesis from $\mathrm{CO}_{2}$ and $\mathrm{CO}$ hydrogenation. The calculations show that $\mathrm{ZrO}_{2}$ has a significant influence on the suppression of the dissociation of $\mathrm{CO}_{2}$ and stabilization of $\mathrm{H}_{2} \mathrm{COO}$ species on the surface of $\mathrm{In}_{2} \mathrm{O}_{3}$ catalyst.

The hydrogenation and dissociation reaction network of carbon monoxide (CO) over a Co-doped $\mathrm{Cu}$ (111) surface were theoretically studied using DFT. The calculated results revealed that the $\mathrm{H}$-assisted route proceeds with the formation of $\mathrm{HCO}, \mathrm{CH}_{2} \mathrm{O}$ and $\mathrm{CH}_{3} \mathrm{O}$ while $\mathrm{OH}$-assisted route proceeds with the formation of $\mathrm{COH}, \mathrm{CHOH}$ and $\mathrm{CH}_{2} \mathrm{OH}$ [33].

The influence of surface hydroxyls over $\mathrm{Ni} / \gamma-\mathrm{Al}_{2} \mathrm{O}_{3}$ and $\mathrm{Cu} / \gamma-\mathrm{Al}_{2} \mathrm{O}_{3}$ has been investigated theoretically by Pan et al. [34] and Zhang et al. [35]. Their calculations show that the hydroxylation of $\gamma-\mathrm{Al}_{2} \mathrm{O}_{3}$ changes the reaction pathway and finally will influence the products distribution and hence, the process selectivity.

Zuo et al. [36] investigated theoretically the $\mathrm{CO}$ and $\mathrm{CO}_{2}$ hydrogenation on $\mathrm{Cu} / \gamma-\mathrm{Al}_{2} \mathrm{O}_{3}$ (110) surface in liquid paraffin. Their results indicated that the synthesis of methanol occurs via the formation of $\mathrm{CHO}, \mathrm{CH}_{2} \mathrm{O}$, and $\mathrm{CH}_{3} \mathrm{O}$ intermediates with $\mathrm{CHO}$ hydrogenation as the rate-limiting step.

With the above analysis, the objective in this work is to study the impact of the nature of the support on the physicochemical properties of Co-based catalyst and its activity in $\mathrm{CO}$ hydrogenation. We investigated the elementary steps resulting in the formation of methanol on $\mathrm{Co} / \mathrm{Al}_{2} \mathrm{O}_{3}$ using the density functional theory (DFT) calculations. $\mathrm{Co}_{4}$ cluster was chosen because $\mathrm{Co}_{4}$ is the smallest cluster that possesses a three-dimensional structure and it could include both metal-metal and metal-support interactions. A model of $\mathrm{Al}_{2} \mathrm{O}_{3}(104)-(2 \times 2 \times 2)$ based on X-ray diffraction (XRD) experimental results was adopted [37].

In our results, firstly we concentrate on the reactants adsorption and the configurations of the key intermediates involved in the process mechanism, followed by the energies.

\section{Model and Computational Methods}

In this study, a model of $\mathrm{Al}_{2} \mathrm{O}_{3}(104)-(2 \times 2 \times 2)$ was selected based on the XRD experimental results [37]. Clusters of $\mathrm{CO}_{4}$ in tetrahedral and rhombus forms were studied to select the stable structure.

The SIESTA (Spanish Initiative for Electronic Simulations with Thousands of Atoms) package based on the DFT approach was used for all geometry and energy calculations [38]. SIESTA has been successfully performed to study on the Fischer-Tropch reaction [39-41] due to its advantages in robust and accurate aspect.

The generalized gradient approximation (GGA) with the Perdew, Burke, and Ernzerhof (PBE) non-local gradient-corrected functional was employed to estimate the exchange correlation energy [42]. According to the large number of atoms in the studied systems (about 100 atoms), the double zeta basis plus polarization orbitals (DZP) was used for valence electrons, while the core electrons were treated using the norm-conserving pseudo potentials (NCP) in its fully non-local (Kleinman-Bylander) 
form [43]. The Coulomb potential was expanded in a plane-wave basis with an energy cut-off of 150 Ryd. The systems were placed in boxes of $25 \times 25 \times 25 \AA$, which are big enough to have negligible electric fields at their edges. Spin-polarized calculations have been performed for all systems including metals. All equilibrium structures were obtained using the quasi-Newton algorithm, and the forces acting on the dynamic atoms all are smaller than $0.05 \mathrm{eV} / \AA$.

When studying the step-by-step conversion of $\mathrm{CO}$ into methanol on the catalytic system, all the transition states were determined using a climbing image nudged elastic band (CI-NEB) method [44]. The advantages of the CI-NEB methods are that after the convergence is reached, the climbing image will converge to the saddle point and all the images occuring in the reaction coordinates are being relaxed simultaneously. In this work, the total number of images involved in the reaction path is seven, including the initial and the final configurations. In the CI-NEB calculations, the convergence tolerance is $0.1 \mathrm{eV} / \AA$ in the magnitude of the forces.

The energy variation is used as a significant criterion to predict the ability and the extent of all the processes. Additionally, to estimate the nature of the adsorbate and substrate interaction, a crucial change in the geometrical parameters was analyzed. Moreover, the atomic partial charges, estimated by means of the Voronoi deformation density (VDD) method, were reported. The VDD method avoids the problems inherent to basis set based schemes and provides meaningful charges that conform to chemical experience [45]. Moreover, the Mayer bond orders were also calculated. The Mayer bond orders are also less dependent on the basis of set choice and they are transferable and can be used to describe similar systems.

\section{Results and Discussion}

\subsection{Electronic Properties of $\mathrm{Co}_{4}$ and $\mathrm{Co}_{4} / \mathrm{Al}_{2} \mathrm{O}_{3}$ Systems}

$\mathrm{Co}_{4}$ clusters were optimized in both tetrahedral and rhombus geometries (Figure 1). The calculated binding energies, $\mathrm{E}_{\mathrm{b}}\left(\mathrm{E}_{\mathrm{b}}=\left[4 \mathrm{E}(\mathrm{M})-\mathrm{E}\left(\mathrm{M}_{4}\right)\right] / 4\right)$ and the numbers of unpaired electrons, $\mathrm{N}_{\mathrm{ue}}$ are presented in Table 1.

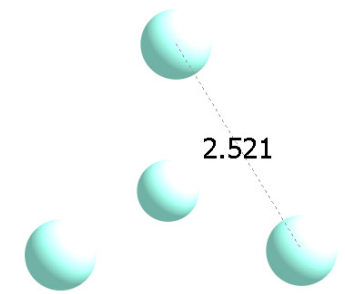

(a)

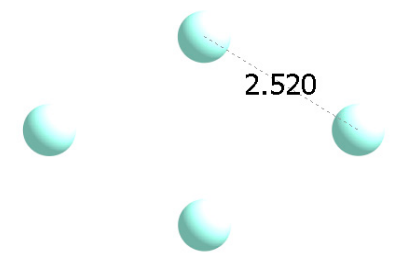

(b)

Figure 1. Tetrahedral (a) and rhombus (b) structures of $\mathrm{Co}_{4}$ cluster; key distances are given in $\AA$.

Table 1. The calculated binding energies $\left(\mathrm{E}_{\mathrm{b}}, \mathrm{eV} / \mathrm{atom}\right)$, the numbers of unpaired electrons $\left(\mathrm{N}_{\mathrm{ue}}\right)$ of $\mathrm{Co}_{4}$ clusters.

\begin{tabular}{ccc}
\hline Structure & $\mathbf{E}_{\mathbf{b}}$ & $\mathbf{N}_{\mathbf{u e}}$ \\
\hline Tetrahedral & 3.86 & 12 \\
Rhombus & 3.41 & 12 \\
\hline
\end{tabular}

The calculated binding energy of the tetrahedral structure is higher than that of the rhombus. Hence, for $\mathrm{Co}_{4}$ cluster the tetrahedral structure is more pronounced.

In our calculations, we have used collinear spin polarized option. The total spin polarization for the optimal structure were automatically determined corresponding to the structure with the lowest energy. Furthermore, the $\mathrm{Co}_{4}$ structure were optimized with the fixed spin corresponding to the presence of 10 or 14 unpaired electrons. The results have confirmed that the $\mathrm{Co}_{4}$ structure with 12 unpaired electrons is the most stable due to the lowest energy (see Supplementary, Table S1). 
It is interesting to note that the $\mathrm{Co}$ atom has three unpaired electrons, while $\mathrm{Co}_{4}$ has 12 unpaired electrons. Thus, the formation of $\mathrm{Co}_{4}$ does not involve the electron pairing. In other words, metallic bonding is present even in clusters as small as $\mathrm{Co}_{4}$. Moreover, the $\mathrm{Co}-\mathrm{Co}$ bond lengths in tetrahedral and rhombus clusters are 2.521 and $2.520 \AA$, respectively which are shorter than twice the atomic radii of Co (1.35 $\AA$, [46]). This again confirms the formation of chemical bonds between cobalt atoms in the cluster structures.

To evaluate the interaction between the clusters and the support, the initial cobalt clusters were placed at several positions on the surface of $\mathrm{Al}_{2} \mathrm{O}_{3}$ and the interaction energies were calculated (See Supplementary, Table S2). By comparing the interaction energy, the most stable structure of $\mathrm{Co}_{4}$ on $\mathrm{Al}_{2} \mathrm{O}_{3}$ was found and is presented in Figure 2.

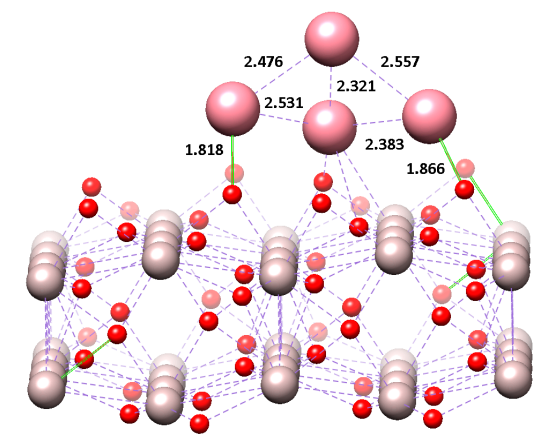

Figure 2. The optimized structure of $\mathrm{Co}_{4} / \mathrm{Al}_{2} \mathrm{O}_{3}$ systems (colors: red-oxygen atom, grey-alumina atoms, violet—cobalt atoms); key distances are given in $\AA$.

The structure of the $\mathrm{Co}_{4}$ cluster on $\mathrm{Al}_{2} \mathrm{O}_{3}$ is close to the tetrahedron, the number of unpaired electrons of $\mathrm{CO}_{4}$ has been reduced to 10 in comparison to the cluster alone. This is attributed to the partly transfer of electrons from the metal clusters to the alumina support. The total atomic charge of $\mathrm{Co}_{4}$ cluster is calculated to be +0.944 which demonstrates the strong interaction between the cluster and the support. Moreover, the closest distance between $\mathrm{Co}$ and $\mathrm{O}$ atoms in $\mathrm{Co}_{4} / \mathrm{Al}_{2} \mathrm{O}_{3}$ system $(1.818 \AA$ ) is shorter than the sum of the atomic radius of $\mathrm{Co}$ and $\mathrm{O}$ atoms (1.95 $\AA$ [46]). Hence, the formation of $\mathrm{Co}_{4} / \mathrm{Al}_{2} \mathrm{O}_{3}$ system is certainly accompanied by the formation of chemical bonds between $\mathrm{Co}$ and $\mathrm{O}$ atoms in $\mathrm{Al}_{2} \mathrm{O}_{3}$. The bonding formation is confirmed by the total Mayer bond order between Co and $\mathrm{O}$, which is determined to be 1.712 .

Due to the formation of chemical bonds the properties of $\mathrm{Co}_{4} / \mathrm{Al}_{2} \mathrm{O}_{3}$ system are expected to differ from initial $\mathrm{CO}_{4}$ cluster.

\subsection{Adsorption of $\mathrm{CO}$ and $\mathrm{H}_{2}$ on $\mathrm{Co}_{4}, \mathrm{Al}_{2} \mathrm{O}_{3}$ and $\mathrm{Co}_{4} / \mathrm{Al}_{2} \mathrm{O}_{3}$ Systems}

\subsubsection{Adsorption of $\mathrm{CO}$ on $\mathrm{Co}_{4}$ and $\mathrm{Co}_{4} / \mathrm{Al}_{2} \mathrm{O}_{3}$ Systems}

The adsorption of $\mathrm{CO}$ on the catalytic systems plays an important role and mainly governs the formation of hydrogenation products. Therefore, a detailed study of the mechanism of this process is essential.

Adsorption of the $\mathrm{CO}$ molecule on transition metals can be defined in terms of donation of electron density from $\mathrm{CO}$ to the metal and $\pi$-back donation of electrons from filled $d$ orbitals on the metal into vacant antibonding $\pi^{*}$ orbitals on the $\mathrm{CO}$ [47]. Hence, $\mathrm{CO}$ is more favorably adsorbed via the $\mathrm{C}$ atom than the $\mathrm{O}$ atom. The calculated results also indicate that when a $\mathrm{CO}$ molecule is adsorbed on $\mathrm{Co}_{4}$ and $\mathrm{Co}_{4} / \mathrm{Al}_{2} \mathrm{O}_{3}$ systems the interaction of $\mathrm{C}-\mathrm{Co}$ is always thermodynamically more favorable compared to the O-Co orientation (see Supplementary, Table S3). With the C-Co orientation, there are two possibilities for the $\mathrm{CO}$ adsorption: $\mathrm{C}$ atom in $\mathrm{CO}$ is bound to one $\mathrm{Co}$ atom (d-1 configuration); and $\mathrm{C}$ atom in $\mathrm{CO}$ is simultaneously bound to two $\mathrm{Co}$ atoms ( $\mathrm{d}-2$ configuration). The optimized configurations of $\mathrm{CO}$ adsorbed on $\mathrm{Co}_{4}$ cluster and $\mathrm{Co}_{4} / \mathrm{Al}_{2} \mathrm{O}_{3}$ system are presented in Table $\mathrm{S} 3$ of Supplementary. 
The optimized structures of the d- 1 and d-2 configurations for the $\mathrm{CO}$ adsorbed on $\mathrm{Co}_{4} / \mathrm{Al}_{2} \mathrm{O}_{3}$ are illustrated in Figure 3. Table 2 summarizes the calculated results of $\mathrm{CO}$ adsorption on $\mathrm{Co}_{4}$ and $\mathrm{Co}_{4} / \mathrm{Al}_{2} \mathrm{O}_{3}$ systems.

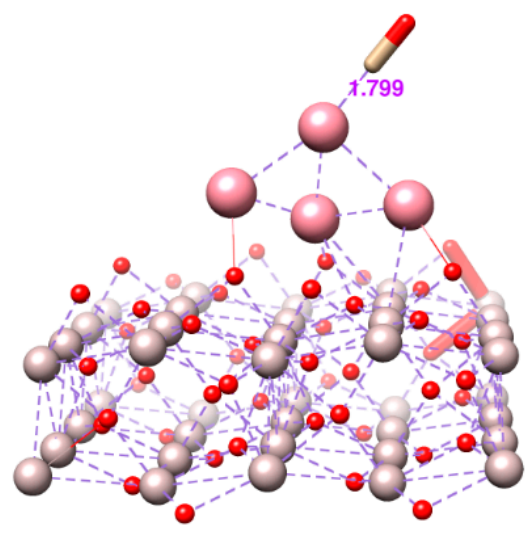

(a)

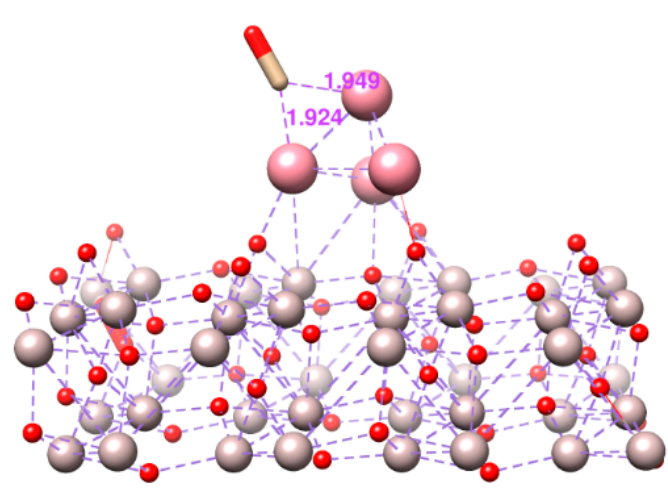

(b)

Figure 3. The optimized structure of the $\mathrm{d}-1$ (a) and d-2 (b) configurations of $\mathrm{CO}-\mathrm{Co}_{4} / \mathrm{Al}_{2} \mathrm{O}_{3}$; (colors: red-oxygen atom, grey—alumina atoms, violet—cobalt atoms); key distances are given in $\AA$.

Table 2. $\mathrm{E}_{\mathrm{ads}}\left(\right.$ in $\mathrm{kJ} \mathrm{mol}^{-1}$ ), $\mathrm{d}_{\mathrm{C}-\mathrm{O}}$ (in $\AA$ ) and bond-dissociation energy (BDE) of $\mathrm{C}-\mathrm{O}$ (in kJ mol ${ }^{-1}$ ).

\begin{tabular}{ccccccc}
\hline Structures & \multicolumn{3}{c}{ d-1 Configuration } & \multicolumn{3}{c}{ d-2 Configuration } \\
\hline & $\mathrm{E}_{\mathrm{ads}}$ & $\mathrm{d}_{\mathrm{C}-\mathrm{O}}$ & $\mathrm{BDE}_{\mathrm{C}-\mathrm{O}}$ & $\mathrm{E}_{\mathrm{ads}}$ & $\mathrm{d}_{\mathrm{C}-\mathrm{O}}$ & $\mathrm{BDE}_{\mathrm{C}-\mathrm{O}}$ \\
$\mathrm{Co}_{4}$ & -186.9 & 1.172 & 960.6 & -201.4 & 1.203 & 928.0 \\
$\mathrm{Co}_{4} / \mathrm{Al}_{2} \mathrm{O}_{3}$ & -231.9 & 1.161 & 1004.3 & -237.3 & 1.179 & 1023.5 \\
$\mathrm{CO}$ & & 1.145 & 1190.3 & & 1.145 & 1190.3 \\
Exp. & & $1.128[48]$ & $1072[49]$ & & & \\
\hline
\end{tabular}

From Table 2, one can see that when $\mathrm{CO}$ molecule is adsorbed on $\mathrm{Co}_{4}$ cluster as well as on the $\mathrm{Co}_{4} / \mathrm{Al}_{2} \mathrm{O}_{3}$ system, the weakness of $\mathrm{C}-\mathrm{O}$ bond results in its elongation and the decrease of bond-dissociation energy. The adsorption energies of $\mathrm{CO}$ on $\mathrm{Co}_{4} / \mathrm{Al}_{2} \mathrm{O}_{3}$ are lower than those on $\mathrm{Co}_{4}$ cluster alone. These results indicate the role of the alumina support: the $\boldsymbol{d}-\mathbf{2}$ configuration $\mathrm{CO}-\mathrm{Co}_{4} / \mathrm{Al}_{2} \mathrm{O}_{3}$ is the most favorable configuration due to the lowest adsorption energy, while the dissociation energy of the $\mathrm{C}-\mathrm{O}$ bond in this configuration is highest. Thus, loading $\mathrm{Co}_{4}$ on the $\mathrm{Al}_{2} \mathrm{O}_{3}$ surface leads to an increase in the $\mathrm{CO}$ adsorption ability but hinder the dissociation of $\mathrm{C}-\mathrm{O}$ bond. In another words, hydrogenation of $\mathrm{CO}$ on $\mathrm{Co}_{4} / \mathrm{Al}_{2} \mathrm{O}_{3}$ likely leads to the formation of oxygen-containing compounds. Notably, the adsorption of $\mathrm{CO}$ on $\mathrm{Co}_{4} / \mathrm{Al}_{2} \mathrm{O}_{3}$ results in the formation of $\mathrm{d}-2$ configuration. In this configuration the number of unpaired electrons is eight, while in the initial $\mathrm{Co}_{4} / \mathrm{Al}_{2} \mathrm{O}_{3}$ system there are 10 unpaired electrons. Hence, two reduced electrons involve and to form a covalent bond between adsorbent and the $\mathrm{CO}$ molecule.

The obtained results regarding to the adsorption ability of $\mathrm{CO}$ on $\mathrm{Co}_{4} / \mathrm{Al}_{2} \mathrm{O}_{3}$ show that $\mathrm{Co}_{4} / \mathrm{Al}_{2} \mathrm{O}_{3}$ can catalyze the hydrogenation of $\mathrm{CO}$ into alcohols.

\subsubsection{Adsorption of $\mathrm{H}_{2}$ on $\mathrm{Co}_{4}$ and $\mathrm{Co}_{4} / \mathrm{Al}_{2} \mathrm{O}_{3}$ Systems}

It has been established that for adsorption of hydrogen on the transition-metal surfaces the dissociative chemisorption is the preferred [50,51]. Our calculated results also revealthat $\mathrm{H}_{2}$ dissociative adsorptions on $\mathrm{Co}_{4}$ cluster and $\mathrm{CO}_{4} / \mathrm{Al}_{2} \mathrm{O}_{3}$ system are favorable due to the lower adsorption energy (in comparison to that for molecular adsorption (see Supplementary, Table S4). The hydrogen adsorption on $\mathrm{Co}_{4} / \mathrm{Al}_{2} \mathrm{O}_{3}$ releases $280.7 \mathrm{~kJ} \mathrm{~mol}^{-1}$. The $\mathrm{H}-\mathrm{H}$ distance is elongated from $0.776 \AA$ (in the isolated molecule) to $3.145 \AA$ (in the adsorption structure). Dissociated hydrogen atoms are simultaneously bound to two metal atoms on the surface of catalysts and thus will come to react with adsorbed $\mathrm{CO}$ molecule in the next reaction steps. 


\subsubsection{Adsorption of $\mathrm{CO}$ and $\mathrm{H}_{2}$ on $\mathrm{Al}_{2} \mathrm{O}_{3}$ System}

For comparison purposes, the adsorption of $\mathrm{CO}$ and $\mathrm{H}_{2}$ on a pure $\mathrm{Al}_{2} \mathrm{O}_{3}$ support is also estimated. The calculations show that $\mathrm{CO}$ molecule is favorably adsorbed horizontally on the $\mathrm{Al}_{2} \mathrm{O}_{3}$ (104) surface at a distance of about 2.6 $\AA$ with an adsorption energy of $-59.8 \mathrm{~kJ} \mathrm{~mol}^{-1}$. The $\mathrm{E}_{\text {ads }}$ for $\mathrm{H}_{2}$ adsorption on $\mathrm{Al}_{2} \mathrm{O}_{3}$ is $-32.7 \mathrm{~kJ} \mathrm{~mol}^{-1}$ and the closest distance of $\mathrm{H}_{2}$ to the $\mathrm{Al}_{2} \mathrm{O}_{3}$ surface is $2.3 \AA$ (see Supplementary, Table S5) which reflects a physisorption in nature. These results indicate that $\mathrm{Al}_{2} \mathrm{O}_{3}$ can play a support role only. It interacts with the $\mathrm{Co}_{4}$ sites to enhance the adsorption efficiency of Co toward $\mathrm{CO}$ and $\mathrm{H}_{2}$.

\subsection{Preliminary Investigation on the Process of $\mathrm{CO}$ Hydrogenation over $\mathrm{Co}_{4} / \mathrm{Al}_{2} \mathrm{O}_{3}$ Catalyst to Methanol}

We consider the first step in the CO conversion process to methanol, this step involves the interaction between $\mathrm{CO}$ and $\mathrm{H}_{2}$ adsorbed molecules.

A schematic diagram of the suggested possible reaction pathway for the $\mathrm{CH}_{3} \mathrm{OH}$ synthesis via the hydrogenation of $\mathrm{CO}$ on the $\mathrm{Co}_{4} / \mathrm{Al}_{2} \mathrm{O}_{3}$ catalyst is presented in Figure $4 \mathrm{a}, \mathrm{b}$.

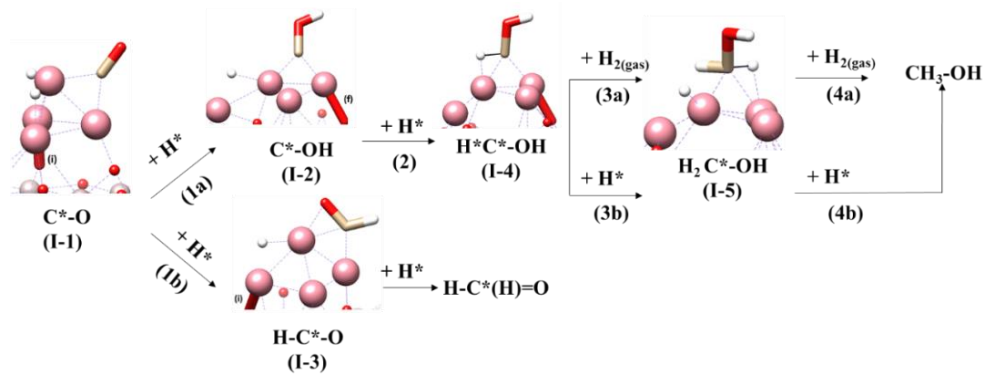

(a)

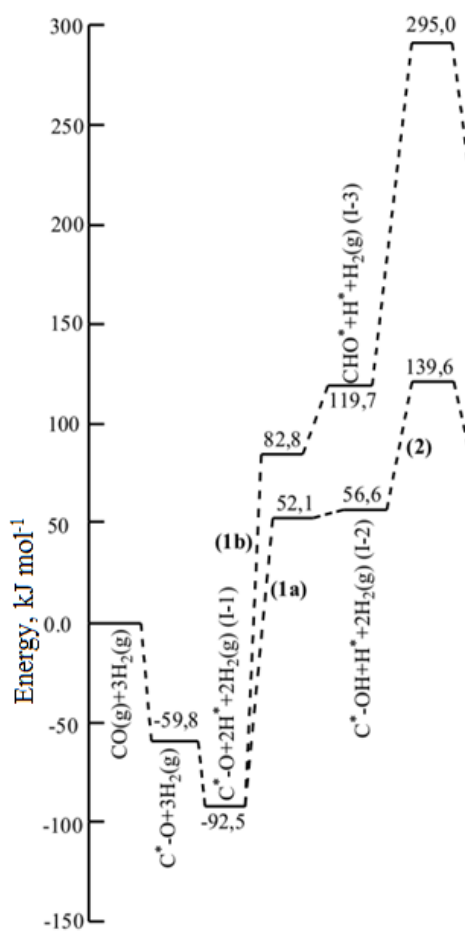

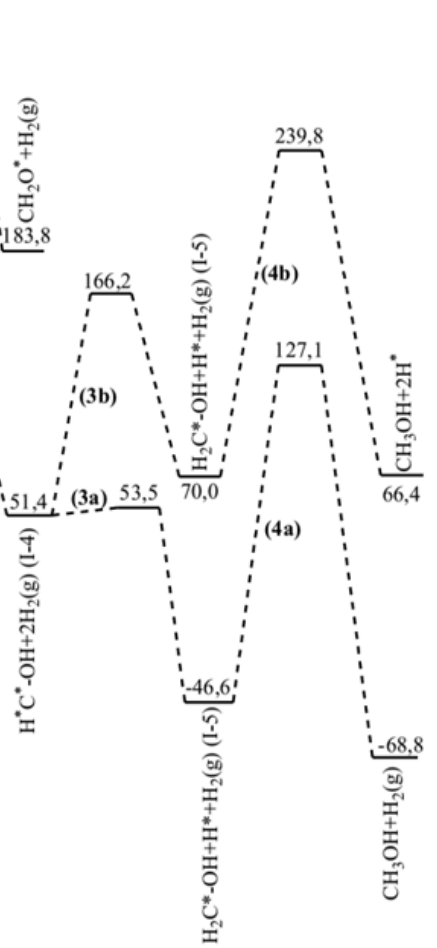

(b)

Figure 4. The possible reaction pathways for the $\mathrm{CH}_{3} \mathrm{OH}$ synthesis via the hydrogenation of $\mathrm{CO}$ on the $\mathrm{Co}_{4} / \mathrm{Al}_{2} \mathrm{O}_{3}$ catalyst (colors: bronze-carbon atom, red-oxygen atom, white-hydrogen atoms, violet—cobalt atoms), symbol “*” denotes the adsorbed species. Potential energy diagram obtained from density functional theory (DFT) calculations for $\mathrm{CH}_{3} \mathrm{OH}$ synthesis via the hydrogenation of $\mathrm{CO}$ on the $\mathrm{Co}_{4} / \mathrm{Al}_{2} \mathrm{O}_{3}$ catalyst, symbol "** denotes the adsorbed species. 
The reaction energy $(\Delta E)$ and the activation energy $\left(E_{a}\right)$ of each stage are defined as:

$$
\begin{aligned}
& \mathrm{E}_{\mathrm{a}}=\mathrm{E}_{\mathrm{TS}}-\mathrm{E}_{\mathrm{IS}} \\
& \Delta \mathrm{E}=\mathrm{E}_{\mathrm{FS}}-\mathrm{E}_{\mathrm{IS}}
\end{aligned}
$$

where $\mathrm{E}_{\mathrm{TS}}, \mathrm{E}_{\mathrm{IS}}$, and $\mathrm{E}_{\mathrm{FS}}$ are the total energies of the transition states (TS), the initial (IS) and final structures (FS), respectively.

The transition state structures of $\mathrm{CO}$ hydrogenation on $\mathrm{Co}_{4} / \mathrm{Al}_{2} \mathrm{O}_{3}$ are presented in Table $\mathrm{S} 6$ of Supplementary. The calculated $\Delta \mathrm{E}$ and $\mathrm{E}_{\mathrm{a}}$ for each step are summarized in Table 3.

\begin{tabular}{|c|c|c|}
\hline Steps & $\Delta \mathrm{E}\left(\mathrm{kJ} \mathrm{mol}{ }^{-1}\right)$ & $\mathrm{E}_{\mathrm{a}}\left(\mathrm{kJ} \mathrm{mol}^{-1}\right)$ \\
\hline $1 \mathrm{a}$ & 149.10 & 144.6 \\
\hline $1 b$ & 212.2 & 175.3 \\
\hline 2 & -5.2 & 83.0 \\
\hline $3 a$ & -97.8 & 2.1 \\
\hline $3 b$ & 18.6 & 114.8 \\
\hline $4 a$ & -22.4 & 173.5 \\
\hline $4 b$ & 47.8 & 221.2 \\
\hline
\end{tabular}

Table 3. The calculated $\Delta \mathrm{E}$ and $\mathrm{E}_{\mathrm{a}}$ for the $\mathrm{CH}_{3} \mathrm{OH}$ synthesis reaction pathways.

Starting from the configuration I- 1 with adsorbed $\mathrm{CO}$ and $\mathrm{H}$ species on the $\mathrm{Co}_{4} / \mathrm{Al}_{2} \mathrm{O}_{3}$ surface (Figure $4 \mathrm{a}, \mathrm{b}$ ), the $\mathrm{CO}$ hydrogenation may firstly occur through two pathways: the adsorbed $\mathrm{CO}$ reacts with the neighboring adsorbed atomic $\mathrm{H}$ to generate the $\mathrm{C}^{*}-\mathrm{OH}(\mathrm{I}-2)$ or $\mathrm{H}-\mathrm{C}^{*}-\mathrm{O}$ (I-3) species (the asterisk denotes the adsorbed species). Optimized structures of I-1, I-2 and I-3 are presented in Figure 5. A comparison of the energies of formation (stability) and activation energies of $\mathrm{COH}$ and $\mathrm{HCO}$ formation by $\mathrm{CO}$ hydrogenation shows that the $\mathrm{C}^{*}-\mathrm{O}-\mathrm{H}$ formation is energetically more favorable than $\mathrm{H}-\mathrm{C}^{*}=\mathrm{O}$ formation. This finding is due to the lower activation energy (lower by $30.7 \mathrm{~kJ} \mathrm{~mol}^{-1}$ ) and lower reaction energy (lower by $63.1 \mathrm{~kJ} \mathrm{~mol}^{-1}$ ) of $\mathrm{COH}$ formation. Thus, $\mathrm{CO}$ hydrogenation is likely to proceed via the $\mathrm{COH}$ pathway. If one considered the I-3 configuration, the remaining adsorbed hydrogen atom $\mathrm{H}^{*}$ may interact with the $\mathrm{C}$ atom of $\mathrm{H}-\mathrm{C}^{*}=\mathrm{O}$ species to form formaldehyde $-\mathrm{HC}(\mathrm{H})=\mathrm{O}$.

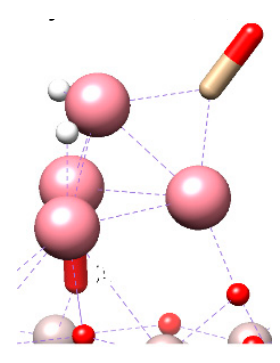

(a)

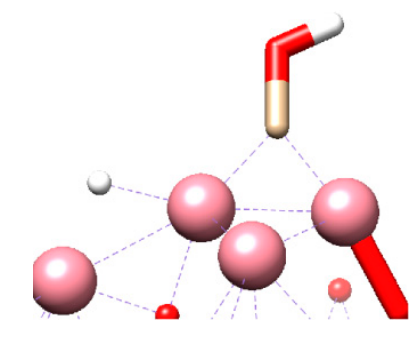

(b)

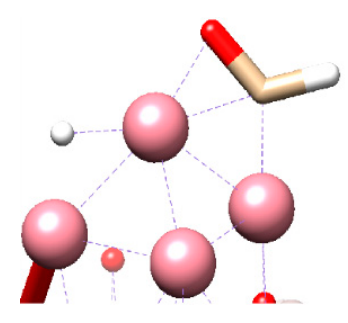

(c)

Figure 5. The optimized structures of I-1 (a), I-2 (b), and I-3 (c) (colors: brown-carbon atom, red-oxygen atom, white—hydrogen atoms, violet—cobalt atoms; symbols (i) and (f) denote the initial and final.

The formation of $\mathrm{C}^{*}-\mathrm{O}-\mathrm{H}$ induced a remarkable change in the geometry of $\mathrm{Co}_{4}$. The $\mathrm{Co}_{4}$ tetrahedron is totally broken and a new $\mathrm{Co}_{4}$ system is formed which is stabilized by the formation of new $\mathrm{Co}-\mathrm{O}$ bond. The initial $\mathrm{Co}-\mathrm{O}$ bond in $\mathrm{I}-1$ structure (denoted as $\mathbf{i}$ in Figure 5) has been broken, a new $\mathrm{Co}-\mathrm{O}$ (in $\mathrm{Al}_{2} \mathrm{O}_{3}$ ) bond is formed in $\mathrm{I}-2$ structure (denoted as $\mathbf{f}$ in Figure 5) and there is no change in the $\mathrm{Co}-\mathrm{O}$ bond in $\mathrm{I}-3$ configuration. This change in structure of $\mathrm{Co}_{4}$ can be attributed to the $\mathrm{Al}_{2} \mathrm{O}_{3}$ support, which stabilizes (strengthens) the $\mathrm{Co}_{4}$ catalyst during the reaction due to the 
formation of $\mathrm{Co}-\mathrm{O}$ bonds. This stabilization may explain for the difference of our result in comparison to Zuo et al.'s calculation [36]. Zuo et al. study the $\mathrm{CO}$ hydrogenation over $\mathrm{Cu}_{2}$ cluster adsorbs onto hydroxylated $\mathrm{Al}_{2} \mathrm{O}_{3}$ (110) surface in liquid paraffin. In their work, methanol was synthesized through the intermediate $\mathrm{CHO}$ rather than $\mathrm{COH}$. Our calculation was based on a cluster of $\mathrm{Co}_{4}$ adsorbed onto $\mathrm{Al}_{2} \mathrm{O}_{3}$ (104) surface. However, our finding is in agreement with the work done by Andersen et al. [15], who study CO hydrogenation over the $\mathrm{MoS}_{2}(100)$ surfaces using DFT calculations. Their results also indicated that the $\mathrm{COH} / \mathrm{HCOH}$ route is more favorable than the $\mathrm{HCO} / \mathrm{H}_{2} \mathrm{CO}$ route on the Mo edge surface. The highest activation barrier in the $\mathrm{COH} / \mathrm{HCOH}$ route is only $134.1 \mathrm{~kJ} \mathrm{~mol}^{-1}$, which is lower than the barrier of $161.1 \mathrm{~kJ} \mathrm{~mol}^{-1}$ for the step forming HCO. These values agree well with our calculations.

From $\mathrm{I}-2, \mathrm{C}^{*}-\mathrm{OH}$ is subsequently hydrogenated to form $\mathrm{H}-\mathrm{C}^{*}-\mathrm{OH}(\mathrm{I}-4)$ through interaction of one adsorbed hydrogen atom with $\mathrm{C}^{*}$ of $\mathrm{C}^{*}-\mathrm{OH}$ :

$$
\mathrm{H}^{*}+\mathrm{C}^{*}-\mathrm{OH} \rightarrow \mathrm{H}-\mathrm{C}^{*}-\mathrm{OH}
$$

Energetically, this process is more dominated because it is exothermic with a negative reaction energy of $\Delta \mathrm{E}\left(-5.2 \mathrm{~kJ} \mathrm{~mol}^{-1}\right)$. The activation energy is determined to be $83.0 \mathrm{~kJ} \mathrm{~mol}^{-1}$.

Experimentally it is well know that at low hydrogen pressure the methanol formation follows the Langmuir-Hinshelwood mechanism, in which both reactants are adsorbed on the catalytic surface and the interactions between adsorbed species. However, at high hydrogen pressure, the reaction might occur via the Eley-Rideal mechanism, in which one reactant in gas phase will come to interact with other adsorbed reactant $[14,52,53]$. Based on this observation we predict two possible pathways to form methanol from $\mathrm{H}-\mathrm{C}^{*}-\mathrm{OH}(\mathrm{I}-4)$ :

(i) In one route (steps 3a-4a), attack of hydrogen molecule from the gas phase with $\mathrm{H}-\mathrm{C}^{*}-\mathrm{OH}$ (I-4) produces $\mathrm{H}_{2} \mathrm{C}^{*}-\mathrm{OH}(\mathrm{I}-5)$. This route is corresponding to the Eley-Rideal mechanism:

$$
\mathrm{H}_{2 \text { (gas) }}+\mathrm{H}-\mathrm{C}^{*}-\mathrm{OH} \rightarrow \mathrm{H}_{2} \mathrm{C}^{*}-\mathrm{OH}+\mathrm{H}^{*}(\text { step 3a) }
$$

The optimized structures of I-4 and I-5 are presented in Figure 6.

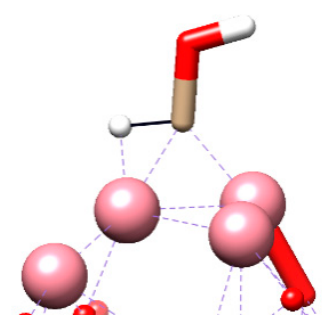

(a)

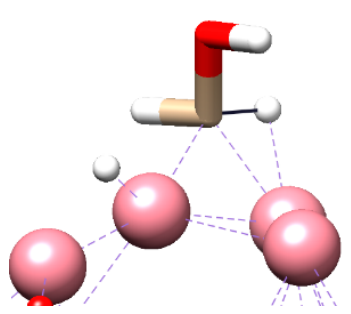

(b)

Figure 6. The optimized structures of I-4 (a) and I-5 (b).

The formed $\mathrm{H}_{2} \mathrm{C}^{*}-\mathrm{OH}(\mathrm{I}-5)$ then subsequently undergoes hydrogenation by another $\mathrm{H}_{2}$ from the gas phase producing $\mathrm{H}_{3} \mathrm{C}^{*}-\mathrm{OH}$ and it will desorb to $\mathrm{CH}_{3} \mathrm{OH}$ product (step 4a).

$$
\mathrm{H}_{2 \text { (gas) }}+\mathrm{H}_{2} \mathrm{C}^{*}-\mathrm{OH} \rightarrow \mathrm{H}_{3} \mathrm{C}^{*}-\mathrm{OH}+\mathrm{H}^{*} \rightarrow \mathrm{CH}_{3} \mathrm{OH}_{\text {gas }}
$$

(ii) In the other route (3b-4b), one adsorbed hydrogen atom on the catalyst surface comes to combine with $\mathrm{H}-\mathrm{C}^{*}-\mathrm{OH}(\mathrm{I}-4)$ forming $\mathrm{H}_{2} \mathrm{C}^{*}-\mathrm{OH}(\mathrm{I}-5)$. The $\mathrm{H}_{2} \mathrm{C}^{*}-\mathrm{OH}$ fragment further reacts with another adsorbed hydrogen atom and followed by desorption to release $\mathrm{CH}_{3} \mathrm{OH}$ (step $4 \mathrm{~b}$ ). This route 
is corresponding to the Langmuir-Hinshelwood mechanism and also has been suggested and calculated by several researchers $[15,22,30,32]$ :

$$
\begin{gathered}
\mathrm{H}^{*}+\mathrm{H}-\mathrm{C}^{*}-\mathrm{OH} \rightarrow \mathrm{H}_{2} \mathrm{C}^{*}-\mathrm{OH} \text { (step 3b) } \\
\mathrm{H}^{*}+\mathrm{H}_{2} \mathrm{C}^{*}-\mathrm{OH} \rightarrow \mathrm{H}_{3} \mathrm{C}^{*}-\mathrm{OH} \rightarrow \mathrm{CH}_{3} \mathrm{OH}_{\text {gas }} \text { (step } 4 \mathrm{~b} \text { ) }
\end{gathered}
$$

The formation of methanol by the direct attack of a hydrogen gas molecule to I-4 is energetically favorable because it is exothermic with a reaction energy of $-97.8 \mathrm{~kJ} \mathrm{~mol}^{-1}$ and an activation energy of $2.1 \mathrm{~kJ} \mathrm{~mol}^{-1}$. Meanwhile, the hydrogenation steps forming $\mathrm{H}_{2} \mathrm{C}^{*}-\mathrm{OH}$ and $\mathrm{H}_{3} \mathrm{C}^{*}-\mathrm{OH}$ through adsorbed hydrogen atoms are kinetically limited due to the higher activation barrier $\left(114.8 \mathrm{~kJ} \mathrm{~mol}^{-1}\right)$.

These calculated results suggest that, at low pressure of $\mathrm{H}_{2}$ and $\mathrm{CO}$ (meaning at low $\mathrm{CO}$ and $\mathrm{H}_{2}$ surface coverages), the $\mathrm{CH}_{3} \mathrm{OH}$ formation will proceeds via consecutive hydrogenation of $\mathrm{C}^{*}$-O fragments by adsorbed hydrogen atom on the catalyst surface to form intermediate species $\mathrm{C}^{*}-\mathrm{OH}, \mathrm{H}-\mathrm{C}^{*}-\mathrm{OH}, \mathrm{H}_{2} \mathrm{C}^{*}-\mathrm{OH}$ and finally, methanol $\mathrm{CH}_{3} \mathrm{OH}$. This would be also consistent with the Langmuir-Hinshelwood mechanism.

However, at high pressure of $\mathrm{H}_{2}$, the reaction pathway will follow the Eley-Rideal mechanism where adsorbed $\mathrm{C}^{*} \mathrm{OH}$ and $\mathrm{HC}^{*} \mathrm{OH}$ species react with molecules $\mathrm{H}_{2}$ from the gas phase in the slow steps of the reaction (steps 3a-4a). The lower activation energies of these steps (3a-4a) compare to those of steps (3b-4b) and the negative values of reaction energies $\left(-97.8\right.$ and $-22.4 \mathrm{~kJ} \mathrm{~mol}^{-1}$ indicating an exothermic nature) calculated by our work correspond well to thermodynamic and kinetic nature of the studied reaction: methanol productivity and rate formation predominates at high pressure.

Generally, In the CO hydrogenation the main reactions which accompany with the methanol synthesis (R1) are the Fischer-Tropsch process (R2) and water-gas shift (WGS) reaction (R3):

$$
\begin{aligned}
\mathrm{CO}+2 \mathrm{H}_{2} & \rightleftharpoons \mathrm{CH}_{3} \mathrm{OH} \\
(2 n+1) \mathrm{H}_{2}+n \mathrm{CO} & \rightarrow \mathrm{C}_{n} \mathrm{H}_{2 n+2}+n \mathrm{H}_{2} \mathrm{O} \\
\mathrm{CO}+\mathrm{H}_{2} \mathrm{O} & \rightleftharpoons \mathrm{CO}_{2}+\mathrm{H}_{2}
\end{aligned}
$$

These reactions are not independent, and any one of them can be expressed as a linear combination of the other two. Also conversion to methanol is limited by equilibrium of the reactions taking place. The synthesis of $\mathrm{CH}_{3} \mathrm{OH}$ from syngas is a equilibrium limited process. It is a high-pressure and exothermic reaction. Increasing pressure results in the reaction of $\mathrm{CO}+2 \mathrm{H}_{2} \rightleftharpoons \mathrm{CH}_{3} \mathrm{OH}$ shifting towards the right hand side. On the other hand, the $\mathrm{CO}$ conversion, the hydrocarbon formation through Fischer-Tropsch (FT) reaction and the production of $\mathrm{CO}_{2}$ from the WGS process significantly increase with increasing temperature, as a result the $\mathrm{CH}_{3} \mathrm{OH}$ selectivity decreases. Therefore, it is necessary to conduct the $\left(2 \mathrm{H}_{2}+\mathrm{CO}\right)$ reaction at high pressures rather than at high temperatures to obtain high $\mathrm{CH}_{3} \mathrm{OH}$ yields.

Ding et al. [52] and Wu et al. [14] studied the kinetics of CO hydrogenation into methanol and found that at high temperature $\left(>330^{\circ} \mathrm{C}\right)$ the alcohol yield was not consistent with the conversion of $\mathrm{CO}$ because at these temperatures the hydrocarbon production is more selective and the WGS reaction becomes significant. The methanol selectivity monotonically decreased with increasing temperature. But increasing the pressure increases the selectivity of methanol, and higher alcohols.

Ladera et al. [53] investigated the hydrogenation of $\mathrm{CO}_{2}$ into methanol over Ga-doped $\mathrm{Cu} / \mathrm{ZnO} / \mathrm{ZrO}_{2}$ catalysts Their investigation shows that the $\mathrm{CH}_{3} \mathrm{OH}$ yield is increased upon increasing the $\mathrm{H}_{2}$ pressure but levels off with the $\mathrm{CO}_{2}$ pressure. The authors suggested that $\mathrm{CH}_{3} \mathrm{OH}$ formation obeys the Eley-Rideal mechanism whereby adsorbed $\mathrm{CO}_{2}$ species $\left(\mathrm{CO}_{2}{ }^{*}\right)$ react with $\mathrm{H}_{2}$ molecule in the slow step of the reaction. 


\section{Conclusions}

In the present study, the elementary steps of $\mathrm{CO}$ hydrogenation leading to the formation of $\mathrm{CH}_{3} \mathrm{OH}$ on $\mathrm{Co}_{4} / \mathrm{Al}_{2} \mathrm{O}_{3}$ were analyzed using the density functional theory calculations. A 4-atom $\mathrm{Co}$ cluster, $\mathrm{Co}_{4}$, was located on the $\mathrm{Al}_{2} \mathrm{O}_{3}$ (104) surface. The calculated results indicated that the formation of $\mathrm{Co}_{4} / \mathrm{Al}_{2} \mathrm{O}_{3}$ systems is accompanied by the formation of chemical bonds between $\mathrm{Co}$ and $\mathrm{O}$ atoms. $\mathrm{CO}$ is more readily absorbed on $\mathrm{Co}_{4} / \mathrm{Al}_{2} \mathrm{O}_{3}$ than on alone a $\mathrm{Co}_{4}$ cluster. In the $\mathrm{CO}$ hydrogenation process, methanol was synthesized through the intermediates $\mathrm{C}^{*}-\mathrm{OH}, \mathrm{H}-\mathrm{C}^{*}-\mathrm{OH}$, and $\mathrm{H}_{2} \mathrm{C}^{*}-\mathrm{OH}$ :

$$
\begin{aligned}
& \mathrm{H}_{2} \rightarrow \mathrm{H}^{*}+\mathrm{H}^{*} \\
& \mathrm{H}^{*}-\mathrm{H}^{*}+\mathrm{C}^{*}-\mathrm{O} \rightarrow \mathrm{H}^{*}+\mathrm{C}^{*}-\mathrm{OH} \\
& \mathrm{H}^{*}+\mathrm{C}^{*}-\mathrm{OH} \rightarrow \mathrm{H}-\mathrm{C}^{*}-\mathrm{OH} \\
& \mathrm{H}_{2}+\mathrm{H}-\mathrm{C}^{*}-\mathrm{OH} \rightarrow \mathrm{H}_{2} \mathrm{C}^{*}-\mathrm{OH}+\mathrm{H}^{*} \\
& \mathrm{H}_{2}+\mathrm{H}_{2} \mathrm{C}^{*}-\mathrm{OH} \rightarrow \mathrm{H}_{3} \mathrm{C}-\mathrm{OH}+\mathrm{H}^{*}
\end{aligned}
$$

Our calculations show that the formation of $\mathrm{C}^{*}-\mathrm{O}-\mathrm{H}$ induced a significant change in the geometry of $\mathrm{Co}_{4}$ and our calculated results show that the interaction between $\mathrm{Al}_{2} \mathrm{O}_{3}$ support and Co catalyst plays a key role in the catalytic hydrogenation of CO to methanol.

The studies have also suggested that the initial steps are kinetically difficult although the $\mathrm{COH} / \mathrm{HCOH}$ pathway is slightly favored more than $\mathrm{HCO} / \mathrm{H}_{2} \mathrm{CO}$ pathway. $\mathrm{CH}_{3} \mathrm{OH}$ synthesis on $\mathrm{Co}_{4} / \mathrm{Al}_{2} \mathrm{O}_{3}$ proceeds through $\mathrm{CO}$ reaction with hydrogen via either an Eley-Rideal or Langmuir-Hinshelwood pathway to form $\mathrm{C}^{*} \mathrm{O}, \mathrm{C}^{*} \mathrm{OH}, \mathrm{HC}^{*} \mathrm{OH}, \mathrm{H}_{2} \mathrm{C}^{*} \mathrm{OH}$ and finally, methanol $\left(\mathrm{CH}_{3} \mathrm{OH}\right)$, with both hydrogenation steps forming $\mathrm{C}^{*}-\mathrm{OH}$ and final product as rate-limiting.

Our DFT results shed light on the effects of $\mathrm{Al}_{2} \mathrm{O}_{3}$ support and the $\mathrm{H}_{2}$ pressure on the reaction pathways for methanol formation from $\mathrm{CO}$ hydrogenation over a Co catalyst. The strong metal-support interaction will lead to high dispersion of active sites. This theoretical study allows us to describe $\mathrm{CO}$ hydrogenation reaction in detail and is capable of explaining the key experimental trend of this important but complex reaction.

Supplementary Materials: The following are available online at http:/ wwww.mdpi.com/2073-4344/9/1/6/s1, Table S1. The calculated energy (Ecluster) of Co4 clusters with different number of unpaired electrons. Table S2. The calculated interation energy (Eint) between $\mathrm{Co} 4$ cluster and $\mathrm{Al}_{2} \mathrm{O}_{3}$. Table S3. The calculated adsorption energies $\left(\mathrm{E}_{\mathrm{ads}}\right.$ ) for the adsorption of $\mathrm{CO}$ on $\mathrm{Co}_{4}$ and $\mathrm{Co}_{4} / \mathrm{Al}_{2} \mathrm{O}_{3}$ systems. Table S4. The calculated adsorption energies ( $\mathrm{E}_{\text {ads }}$ ) for the adsorption of $\mathrm{H}_{2}$ on $\mathrm{CO}_{4}$ and $\mathrm{Co}_{4} / \mathrm{Al}_{2} \mathrm{O}_{3}$ system. Table S5. The calculated adsorption energies ( $\mathrm{E}_{\text {ads }}$ ) for the adsorption of $\mathrm{CO}$ and $\mathrm{H}_{2}$ on $\mathrm{Al}_{2} \mathrm{O}_{3}$ system. Table S6. Transition state structures of $\mathrm{CO}$ hydrogenation on $\mathrm{Co} 4 / \mathrm{Al}_{2} \mathrm{O}_{3}$.

Author Contributions: Conceptualization, L.M.C. and N.N.H.; Methodology, N.N.H. and N.T.T.H.; Formal Analysis, L.M.C. and N.N.H.; Investigation, N.N.H., N.T.T.H. and N.B.L.; Data Curation, N.T.T.H. and N.B.L.; Writing-Original Draft Preparation, N.N.H. and N.T.T.H.; Writing-Review andEditing, L.M.C. and N.T.T.H.; Visualization, L.M.C. and N.T.T.H.; Project Administration, L.M.C.

Funding: This research was funded by the Vietnam Ministry of Education and Training, grant number B2015-17-69.

Conflicts of Interest: The authors declare no conflict of interest. The founding sponsors had no role in the design of the study; in the collection, analyses, or interpretation of data; in the writing of the manuscript; and in the decision to publish the results.

\section{References}

1. Surisetty, V.R.; Dalai, A.K.; Kozinski, J. Alcohols as alternative fuels: An overview. Appl. Catal. A 2011, 404, 1-11. [CrossRef]

2. Saeidi, S.; Amin, N.A.S.; Rahimpour, M.R. Hydrogenation of $\mathrm{CO}_{2}$ to value-added products-A review and potential future developments. J. CO2 Util. 2014, 5, 66-81. [CrossRef] 
3. Hu, B.; Yin, Y.; Liu, G.; Chen, S.; Tsang, S.C.E. Hydrogen spillover enabled active Cu sites for methanol synthesis from $\mathrm{CO}_{2}$ hydrogenation over Pd doped CuZn catalysts. J. Catal. 2018, 359, 17-26. [CrossRef]

4. Abrol, S.; Hilton, C.M. Modeling, simulation and advanced control of methanol production from variable synthesis gas feed. Comput. Chem. Eng. 2012, 40, 117-131. [CrossRef]

5. Su, X.; Xu, J.; Liang, B.; Duan, H.; Hou, B.; Huang, Y. Catalytic carbon dioxide hydrogenation, to methane: A review of recent studies. J. Energy Chem. 2016, 25, 553-565. [CrossRef]

6. Weststrate, C.J.; van de Loosdrecht, J.; Niemantsverdriet, J.W. Spectroscopic insights into cobalt catalyzed Fischer-Tropsch synthesis: A review of the carbon monoxide interaction with single crystalline surfaces of cobalt. J. Catal. 2016, 342, 1-16. [CrossRef]

7. Liu, Y.; Murata, K.; Inaba, M.; Takahara, I.; Okabe, K. Mixed alcohols synthesis from syngas over Cs- and Ni-modified $\mathrm{Cu} / \mathrm{CeO}_{2}$ catalysts. Fuel 2013, 104, 62-69. [CrossRef]

8. Park, N.; Park, M.J.; Lee, Y.J.; Ha, K.S.; Jun, K.W. Kinetic modeling of methanol synthesis over commercial catalysts based on three-site adsorption. Fuel Process. Technol. 2014, 125, 139-147. [CrossRef]

9. Liu, Y.; Deng, X.; Han, P.; Huang, W. CO hydrogenation to higher alcohols over CuZnAl catalysts without promoters: Effect of $\mathrm{pH}$ value in catalyst preparation. Fuel Process. Technol. 2017, 167, 575-581. [CrossRef]

10. Bai, Y.; He, D.; Ge, S.; Liu, H.; Liu, J.; Huang, W. Influences of preparation methods of $\mathrm{ZrO}_{2}$ support and treatment conditions of $\mathrm{Cu} / \mathrm{ZrO}_{2}$ catalysts on synthesis of methanol via $\mathrm{CO}$ hydrogenation. Catal. Today 2010, 149, 111-116. [CrossRef]

11. Studt, F.; Abild-Pedersen, F.; Wu, Q.; Jensen, A.D.; Temel, B.; Grunwaldt, J.D.; Nørskov, J.K. CO hydrogenation to methanol on Cu-Ni catalysts: Theory and experiment. J. Catal. 2012, 293, 51-60. [CrossRef]

12. Chai, S.H.; Schwartz, V.; Howe, J.Y.; Wang, X.; Kidder, M.; Overbury, S.H.; Dai, S.; Jiang, D.E. Graphitic mesoporous carbon-supported molybdenum carbides for catalytic hydrogenation of carbon monoxide to mixed alcohols. Microporous Mesoporous Mater. 2013, 170, 141-149. [CrossRef]

13. Surisetty, V.R.; Eswaramoorthi, I.; Dalai, A.K. Comparative study of higher alcohols synthesis over alumina and activated carbon-supported alkali-modified $\mathrm{MoS}_{2}$ catalysts promoted with group VIII metals. Fuel 2012, 96, 77-84. [CrossRef]

14. Wu, Q.; Christensen, J.M.; Chiarello, G.L.; Duchstein, L.D.; Wagner, J.B.; Temel, B.; Grunwaldt, J.D.; Jensen, A.D. Supported molybdenum carbide for higher alcohol synthesis from syngas. Catal. Today 2013, 215, 162-168. [CrossRef]

15. Andersen, A.; Kathmann, S.M.; Lilga, M.A.; Albrecht, K.O.; Hallen, R.T.; Mei, D. Effects of potassium doping on $\mathrm{CO}$ hydrogenation over $\mathrm{MoS}_{2}$ catalysts: A first-principles investigation. Catal. Commun. 2014, 52, 92-97. [CrossRef]

16. Gnanamani, M.K.; Jacobs, G.; Keogh, R.A.; Shafer, W.D.; Sparks, D.E.; Hopps, S.D.; Thomas, G.A.; Davis, B.H. Fischer-Tropsch synthesis: Effect of pretreatment conditions of cobalt on activity and selectivity for hydrogenation of carbon dioxide. Appl. Catal. A 2015, 499, 39-46. [CrossRef]

17. Wang, P.; Zhang, J.; Bai, Y.; Xiao, H.; Tian, S.; Xie, H.; Yang, G.; Tsubaki, N.; Han, Y.; Tan, Y. Ternary copper-cobalt-cerium catalyst for the production of ethanol and higher alcohols through $\mathrm{CO}$ hydrogenation. Appl. Catal. A 2016, 514, 14-23. [CrossRef]

18. Du, H.; Zhu, H.; Liu, T.; Zhao, Z.; Chen, X.; Dong, W.; Lu, W.; Luo, W.; Ding, Y. Higher alcohols synthesis via CO hydrogenation on Fe-promoted Co/AC catalysts. Catal. Today 2017, 281, 549-558. [CrossRef]

19. Nikparsaa, P.; Mirzaeia, A.A.; Atashib, H. Effect of reaction conditions and Kinetic study on the Fischer-Tropsch synthesis over fused $\mathrm{Co} \mathrm{Ni} / \mathrm{Al}_{2} \mathrm{O}_{3}$ catalyst. J. Fuel Chem. Technol. 2014, 42, 710-718. [CrossRef]

20. Zhang, Y.; Sun, Q.; Deng, J.; Wu, D.; Chen, S. A high activity $\mathrm{Cu} / \mathrm{ZnO} / \mathrm{Al}_{2} \mathrm{O}_{3}$ catalyst for methanol synthesis: Preparation and catalytic properties. Appl. Catal. A 1997, 158, 105-120. [CrossRef]

21. Li, D.; Yang, C.; Li, W.; Sun, Y.; Zhong, B. Ni/ADM: A high activity and selectivity to $\mathrm{C}_{2+} \mathrm{OH}$ catalyst for catalytic conversion of synthesis gas to $\mathrm{C}_{1}-\mathrm{C}_{5}$ mixed alcohols. Top. Catal. 2005, 32, 233-239. [CrossRef]

22. Shi, X.R.; Jiao, H.; Hermann, K.; Wang, J. CO hydrogenation reaction on sulfided molybdenum catalysts. J. Mol. Catal. A Chem. 2009, 312, 7-17. [CrossRef]

23. Díez-Ramírez, J.; Sánchez, P.; Kyriakou, V.; Zafeiratos, S.; Marnellos, G.E.; Konsolakis, M.; Dorado, F. Effect of support nature on the cobalt-catalyzed $\mathrm{CO}_{2}$ hydrogenation. J. CO2 Util. 2017, 21, 562-571. [CrossRef]

24. Zuo, Z.J.; Han, P.D.; Li, Z.; Hu, J.S.; Huang, W. Can methanol be synthesized from CO by direct hydrogenation over Cu/ZnO catalysts? Appl. Surf. Sci. 2012, 261, 640-646. [CrossRef] 
25. Lee, J.H.; Reddy, K.H.; Jung, J.S.; Yang, E.H.; Moon, D.J. Role of support on higher alcohol synthesis from syngas. Appl. Catal. A 2014, 480, 128-133. [CrossRef]

26. Medford, A.J.; Sehested, J.; Rossmeisl, J.; Chorkendorff, I.; Studt, F.; Nørskov, J.K.; Moses, P.G. Thermochemistry and micro-kinetic analysis of methanol synthesis on $\mathrm{ZnO}$ (0001). J. Catal. 2014, 309, 397-407. [CrossRef]

27. Prasad, P.S.; Bae, J.; Jun, K.-W.; Lee, K.-W. Fischer-Tropsch Synthesis by Carbon Dioxide Hydrogenation on Fe-Based Catalysts. Catal. Surv. Asia 2008, 12, 170-183. [CrossRef]

28. Reuel, R.C.; Bartholomew, C.H. Effects of support and dispersion on the CO hydrogenation activity/selectivity properties of cobalt. J. Catal. 1984, 85, 78-88. [CrossRef]

29. Zhao, Y.; Rousseau, R.; Li, J.; Mei, D. Theoretical study of syngas hydrogenation to methanol on the polar Zn-terminated ZnO (0001) surface. J. Phys. Chem. C 2012, 116, 15952-15961. [CrossRef]

30. Reimers, W.; Zubieta, C.; Baltan'as, M.A.; Branda, M.M. A DFT Approach for Methanol Synthesis via Hydrogenation of CO on Gallia, Ceria and ZnO surfaces. Appl. Surf. Sci. 2018, 436, 1003-1017. [CrossRef]

31. Liuan, P.; Yang, Y.; White, M.G. Theoretical perspective of alcohol decomposition and synthesis from $\mathrm{CO}_{2}$ hydrogenation. Surf. Sci. Rep. 2013, 68, 233-272. [CrossRef]

32. Dou, M.; Zhang, M.; Chen, Y.; Yu, Y. Theoretical Study of Methanol Synthesis from $\mathrm{CO}_{2}$ and $\mathrm{CO}$ Hydrogenation on the surface of $\mathrm{ZrO}_{2}$ supported $\mathrm{In}_{2} \mathrm{O}_{3}$ catalyst. Surf. Sci. 2018, 672-673, 7-12. [CrossRef]

33. Zha, H.; Dong, X.; Yu, Y.; Zhang, M. Hydrogen-assisted versus Hydroxyl-assisted CO Dissociation over Co-doped Cu(111): A DFT Study. Surf. Sci. 2018, 669, 114-120. [CrossRef]

34. Pan, Y.X.; Liu, C.J.; Ge, Q. Effect of surface hydroxyls on selective $\mathrm{CO}_{2}$ hydrogenation over $\mathrm{Ni}_{4} / \gamma-\mathrm{Al}_{2} \mathrm{O}_{3}: \mathrm{A}$ density functional theory study. J. Catal. 2010, 272, 227-234. [CrossRef]

35. Zhang, R.G.; Wang, B.J.; Liu, H.Y.; Ling, L.X. Effect of surface hydroxyls on $\mathrm{CO}_{2}$ hydrogenation over $\mathrm{Cu} / \gamma$ $-\mathrm{Al}_{2} \mathrm{O}_{3}$ catalyst: A theoretical study. J. Phys. Chem. C 2011, 115, 19811-19818. [CrossRef]

36. Zuo, Z.J.; Wang, L.; Han, P.D.; Huang, W. Methanol synthesis by $\mathrm{CO}$ and $\mathrm{CO}_{2}$ hydrogenation on $\mathrm{Cu} / \gamma-\mathrm{Al}_{2} \mathrm{O}_{3}$ surface in liquid paraffin solution. Appl. Surf. Sci. 2014, 290, 398-404. [CrossRef]

37. Yang, Z.; Yu, J.; Li, C.; Zhong, Y.; Xuan, W.; Ren, Z.; Wang, Q.; Dai, Y.; Wang, H. Preparation of textured porous $\mathrm{Al}_{2} \mathrm{O}_{3}$ ceramics by slip casting in a strong magnetic field and its mechanical properties. Cryst. Res. Technol. 2015, 50, 645-653. [CrossRef]

38. Soler, J.M.; Artacho, E.; Gale, J.D.; García, A.; Junquera, J.; Ordejón, P.; Sánchez-Portal, D. The SIESTA method for ab initio order-N materials simulation. J. Phys. Condens. Matter 2002, 14, 2745-2779. [CrossRef]

39. Cheng, J.; Hu, P.; Ellis, P.; French, S.; Kelly, G.; Lok, C.M. A DFT study of the chain growth probability in Fischer-Tropsch synthesis. J. Catal. 2008, 257, 221-228. [CrossRef]

40. Cheng, J.; Hu, P.; Ellis, P.; French, S.; Kelly, G.; Lok, C.M. Chain growth mechanism in Fischer-Tropsch synthesis: A DFT study of C-C coupling over Ru, Fe, Rh, and Re surfaces. J. Phys. Chem. C 2008, 112, 6082-6086. [CrossRef]

41. Cheng, J.; Gong, X.Q.; Hu, P.; Lok, C.M.; Ellis, P.; French, S. A quantitative determination of reaction mechanisms from density functional theory calculations: Fischer-Tropsch synthesis on flat and stepped cobalt surfaces. J. Catal. 2008, 254, 285-295. [CrossRef]

42. Perdew, J.P.; Burke, K.; Ernzerhof, M. Generalized Gradient Approximation Made Simple. Phys. Rev. Lett. 1996, 77, 3865-3868. [CrossRef] [PubMed]

43. Hamann, D.R.; Schlüter, M.; Chiang, C. Norm-conserving pseudopotentials. Phys. Rev. Lett. 1979, 43, 1494-1497. [CrossRef]

44. Henkelman, G.; Uberuaga, B.P.; Jónsson, H. A climbing image nudged elastic band method for finding saddle points and minimum energy paths. J. Chem. Phys. 2000, 133, 9901-9904. [CrossRef]

45. Fonseca Guerra, C.; Handgraaf, J.-W.; Baerends, E.J.; Bickelhaupt, F.M. Voronoi deformation density (VDD) charges: Assessment of the Mulliken, Bader, Hirshfeld, Weinhold, and VDD methods for charge analysis. J. Comput. Chem. 2004, 25, 189-210. [CrossRef]

46. Slater, J.C. Atomic Radii in Crystals. J. Chem. Phys. 1964, 41, 3199-3205. [CrossRef]

47. Fielicke, A.; Gruene, P.; Meijer, G.; Rayner, D.M. The adsorption of CO on transition metal clusters: A case study of cluster surface chemistry. Surf. Sci. 2009, 603, 1427-1433. [CrossRef]

48. Huber, K.P.; Herzberg, G. Molecular Spectra and Molecular Structure, IV. Constants of Diatomic Molecules; Van Nostrand Reinhold Company: New York, NY, USA, 1979.

49. Cottrell, T.L. The Strengths of Chemical Bonds, 2nd ed.; Butterworths: London, UK, 1958. 
50. Nordlander, P.; Holloway, S.; Nørskov, J.K. Hydrogen adsorption on metal surfaces. Surf. Sci. 1984, 136, 59-81. [CrossRef]

51. Ferrin, P.; Kandoi, S.; Nilekar, A.U.; Mavrikakis, M. Hydrogen adsorption, absorption and diffusion on and in transition metal surfaces: A DFT study. Surf. Sci. 2012, 606, 679-689. [CrossRef]

52. Ding, M.; Qiu, M.; Liu, J.; Li, Y.; Wang, T.; Ma, L.; Wu, C. Influence of manganese promoter on co-precipitated $\mathrm{Fe}-\mathrm{Cu}$ based catalysts for higher alcohols synthesis. Fuel 2013, 109, 21-27. [CrossRef]

53. Ladera, R.; Pérez-Alonso, F.J.; González-Carballo, J.M.; Ojeda, M.; Rojas, S.; Fierro, J.L.G. Catalytic valorization of $\mathrm{CO}_{2}$ via methanol synthesis with Ga-promoted $\mathrm{Cu}-\mathrm{ZnO}-\mathrm{ZrO}_{2}$ catalysts. Appl. Catal. B Environ. 2013, 142-143, 241-248. [CrossRef] 